\title{
On the Development of a Maritime English Visual-Audio-Lingual Course Book
}

\author{
GAO Song \\ English Department, Qingdao Ocean Shipping Mariners College, Qingdao 266071, China
}

\begin{abstract}
Presently, with the higher requirements of maritime education and training, the development of maritime visual-audio-lingual course books are lagging behind, in that the contents are outdated, dull and away from the actual practice. They can by no means reflect the production of ocean transportation and run counter to the principles of language communication, resulting in a severe lap in the aspects of contents, quality and formation. Maritime visual-audio-lingual teaching belongs to ESP and its contents should give prominence to practice and operation, such as, instruments, equipment, machinery and principles; operation, entering and leaving ports, loading and discharging of cargo, navigation and communication, berthing and unberting, heaving anchor, etc. Many scenes and processes are not to be demonstrated by verbal means and normal methods of teaching. Therefore, a set of course book that reflects the real operational situations is of great need and one that adopts the multi-media means in visual-audio-lingual teaching is of enormous and irreplaceable privilege, in that a highly qualified visual-audio-lingual course book will provide real, clear-cut and understandable working situations, so that students will be on-scene and impressed. It will not only improve the students' attention and learning interest, but also help learn practical English in real environment.
\end{abstract}

Key words: Maritime English teaching, real working situations, teaching methodology, maritime English visual-audio-lingual course book.

\section{The Development of "Maritime English Visual-Audio-Lingual Course Book"}

The visual-audio-lingual ability of English is the inseparable integrity in people's routine work and daily life. In accordance with the practice and experience of English teaching and studies, maritime English visual-audio-lingual teaching has the following functions. (1) Giving prominence to the function of modern multimedia teaching, providing real language situation and "visualizing the abstract materials [1]"; (2) Inspiring the learning interest, developing the learning potentials, forming a unity of learning needs and motivation in mind and behavior; (3) Concentrating the attention of the students, which is the initial and critical element in the process of learning and the concentration produced by the stimulation of sound and vision is the premise for the

Corresponding author: GAO Song, associate professor, research fields: maritime English teaching and research, applied linguistics, TEFL, TESOL. happening of learning activity; (4) Improving the students' memory, where the biggest obstacle for English learning is "failure in memory" and as the psychologists say, repetition, reiteration and reappearance are necessary in order to further understand certain contents [2]". Maritime English visual-audio-lingual teaching provides a channel of repetition and reiteration for the students and in turn promotes the effect of memory; (5) Favoring the integrated training of the visual-audio-lingual abilities. The purpose of a language is to communicate information and express ideas. Statistics show that, in the process of information communication, listening and speaking take up $45 \%$ and $30 \%$ and in the absorption of knowledge, vision and listening take up $83 \%$ and $11 \%$. Therefore, as Comenius [3] said, "within the possible scope, it is necessary to absorb the knowledge, promote the memory and acquire the skills via the joining of various organs"; (6) Benefiting the students in establishing a connection 
between old and new knowledge and favoring the inter-influence and mutual improvement of multi language skills.

Therefore, in combination with the practice of oceangoing production, the development of a set of high quality visual-audio-lingual maritime English course book with the contents recorded and processed on site is the common need for the shipping industry, maritime education, training institutions and oceangoing seafarers.

Hence the research project of "Development of Maritime Visual-Audio-Lingual English Textbook Based on Shipping Production and Operation" against the background.

The project was set up in July, 2013 in China Ocean Shipping (Group) Company, with an investment of 200 thousand Yuan, with the convenience for the project research, technical, professional support, onboard filming and data collection thus provided. The research group, under Associate Professor, Gao Song, took three years in developing the original and full "Maritime English Visual-Audio-Lingual Course Book".

\subsection{Preparation}

(1) Training for course book compiling techniques. The group made extensive investigations in the status quo of maritime English visual-audio-lingual teaching in maritime higher institutions, evaluated all the textbooks in use, invited senior scholars in the training of theories and practices for textbook compilation and determined the pattern, style, difficulty level and practice contents of the course book and the practical needs in normal teaching.

(2) The group held regular meetings, collected and studied the existing videos and pictures (including the video materials provided by CCTV, students onboard and practice, etc) and read the relevant materials for reference.

(3) The group studied the IMO Standard Maritime Communication Phrases, Model Courses, teaching and examination syllabuses of China Maritime Safety Administration and collected opinions and suggestions from the shipping industries, maritime English teachers, returning seafarers and maritime undergraduates.

(4) The group formulated the initial plans for the contents and chapters of the course book, made the filming schedules, purchased equipment, conducted the operational training and managed the embarkation formalities.

\subsection{Filming and Recording Onboard}

May 29th, 2014, the project group embarked the container ship "COSCO France" in Qingdao on the northwest European line for a full voyage, 77 days. The ship visited the ports of Qingdao, Shanghai, Ningbo, Hong Kong, Singapore, Suez Canal, Felixstowe, Rotterdam, Hamburg, Antwerp, Singapore, Hong Kong, Shanghai, Tianjin, Dalian and came back to Qingdao. The group formulated detailed plans and tasks in accordance with the voyage plan and the filming contents, including: (1) Introduction of the ship and interview on the crew, ship style and duties, interviews, working situations and drills; (2) Entering and leaving ports, the processes and operations; (3) Navigation at sea, transiting the English and Dover straits, Mediterranean coasts, canals, piracy areas, pilot stations, communications launching and heaving anchors; (4) Sailing operations, overtaking operation and crossing situation, etc.; (5) Cargo operation, company and port inspection, agency, maintenance and repair; (6) Navigation instruments, radar, electronic and paper charts, AIS information; (7) Drills and exercises, firefighting, flooding, man overboard and ship abandoning, etc.

The group made prompt copying and sorting after filming, conducted discussion and reflection and made new plans and schedules.

August, 2014, on completion of material and data collection, the group returned to Qingdao, with 2,358 videos, 6,215 photos and 315 G's of ship materials. 


\subsection{Processing of the Material}

(1) The principles for data processing are vividness, briefness and being practical, coming handy for the students to learn about the production practice at sea, learning of the language in use and teaching in and after classroom;

(2) The group rendered categorization and editing of the audio and video materials, matched with scripts and provided processing with the assistance of language teachers;

(3) The group also recombined the audio-video materials with scripts and compiled all the raw materials into a complete set of textbook in accordance with the order from an undergraduate to a seafarer, practical operation at sea, the ladder situation of language learning and the pattern of progress making of the students;

(4) The group then conducted studies on all the materials, put forth teaching methods and styles and provided guides and suggestions for teachers and students.

On completion, the course book is composed of 10 modules.

Module 1. Introduction of the ship, ship main particulars, bridge, head and stern, deck machinery, living quarters, with on-site introduction by the master, duty officers and sailors;

Module 2. Composition and duties of deck personnel, introduced by the master;

Module 3. Leaving port, including mooring operation, making fast and letting go of tugs, bridge wing operations and disembarkation of pilots;

Module 4. Navigation at sea, head-on situations, overtaking, close-quarter situations and others, as night sailing, and operation on severe weathers, etc.;

Module 5. Transiting Suez Canal, up north and down south reports, including anchoring, convoys and introduction of canal transiting;

Module 6. Communication at sea, with pilot station and boat, VTS, coast guards, danger and safety information, with convoy and agency, etc.;
Module 7. Casting and heaving anchor operation, process and results;

Module 8. Drills at sea, fire prevention, oil spill, ship abandoning, piracy prevention, training and evaluation, etc.;

Module 9. Entering port, embarkation of pilot and all the processes of entering port operation;

Module 10. Cargo operation, including loading and discharging of containers and major bulk, company inspection, ship repair, cargo stowage, customs and immigration inspection, etc.

The whole course book is composed of 66 lively, complete, authentic and practical videos, with dubbing, scripts, notes and exercises, which fills the blank of maritime English visual-audio-lingual course books.

\section{Characteristics of the Maritime English Visual-Audio-Lingual Course Book}

The "Maritime English Visual-Audio-Lingual Course Book" has 10 chapters, 240 pages and 300 thousand words. Based on the contents of the videos, each chapter is divided into four parts. Part One is maritime English vocabulary and standard phrases; Part Two is authentic listening and speaking tasks, with multiple choices, charts, filling in the blanks, questions and answers, reading aloud, retelling, role playing and situational conservations; Part Three is notes for texts, long sentences and difficult points and Part Four is original audios and videos for the reference of the students.

The "Maritime English Visual-Audio-Lingual Course Book" closely follows the principles for compiling English course books and reflects the innovative characteristics.

(1) Authenticity. This being the first set of maritime English visual-audio-lingual course book completely based on the practical situations of oceangoing transportation home and abroad, the full audio-video-lingual materials are composed of real situation recording, not only providing real and lively language and its use, but also offering an opportunity 
for the students to know the practical life and work of seafarers. The elaborated audio and video materials are featured in effect and reflection and will greatly improve the learning interest and effect of the students;

(2) Target oriented. Based on major sections, the course book is further categorized, guided by needs analysis with complete outlines, covering all the contents and requirements within the scope of relevant duties and responsibilities. It aims at the largest and most advanced 13386 TEU container vessel, "COSCO France," which represents the advanced technology and production power and gives adequate considerations and combination of the language basis, learning interest, motivation and objectives of the students;

(3) Use as a tool book. The course book has full and detailed contents, covering all the aspects of life and work of oceangoing seafarers and can be well used as a textbook for maritime undergraduates and consultancy and reference for on-duty seafarers;

(4) Diverseness. The course book with its audios and videos is realistic, practical, convenient and elaborated, with dubbing, notes and explanations, with prominent contents and beautiful pictures and is also suitable for autonomous learning of the students in extracurricular atmosphere;

(5) Stereoscopic. With the continued development of the information technology, the channel of information takes the form of multimodality and students' knowledge learning is no longer dependent solely on textbooks and classroom, neither is it limited in time and place. As the "Maritime English Visual-Audio-Lingual Course Book" contains authentic English, pictures and audios, fluent and typical for the practice of maritime English, it favors the students in learning and practicing maritime English in different styles and benefits the students in learning via various manners, as classroom learning, autonomous learning, cooperative learning and inquiry learning;
(6) Practicality. The course book is developed with reference to the requirements of international conventions and domestic regulations, IMO SMCP, Model Course, Manila Amendments to STCW Convention, teaching and examination syllabuses of China MSA. Its language aspects are modified by expert maritime English teachers and maritime contents authorized by senior masters and seafarers;

(7) Task-based. With the appearance of new language teaching ideologies and methodologies, the state of student-centeredness is further enforced, hence the task-based teaching methodology. The development of the "Maritime English Visual-Audio-Lingual Course Book" reflects the advanced thought of "doing things with the language [4]" in that, each chapter contains different tasks, with the relevant situations, vocabulary, phases, audio-video requirements and communication strategies for students to choose and use. The completion of tasks is the object of learning and practice, so that the students acquire the language through the completion of tasks.

\section{Teaching Methodologies Recommended}

In accordance with the linguistic theories and practice, the success of language learning lies in: (1) the will of learning and using English; (2) authentic English learning materials; (3) adequate chances for practicing English; and (4) correct English teaching methodology. As the "Maritime English Visual-Audio-Lingual Course Book" reflects the foregoing facts in general, it is well used in teaching flexibly with various methodologies and styles. This paper does intend to dwell upon the widely used audio-video, communicative and task-based methodologies, but will comment on three new practices centering round the use of the course book.

\subsection{Interactive Method}

The cognitive theories hold that, the process of learning is one, under the guidance of the teachers, in 
which the students complete the acquisition of knowledge and skills through the experience of their own and interaction of various sorts. English linguist Firth believes that a language is characterized in information interaction and interpersonal interaction. Halliday puts forth that the main function of a language is interaction, while Buck believes that the interactive function of a language is used in maintaining the social relations. Therefore, interaction is the main characteristic of a language and interactive teaching complies with the principles of language learning. Teachers using interactive method in teaching maritime English should have three kinds of knowledge, (1) rules of a language, so that the teacher can implement the task of teaching; (2) cognitive theories, where the basic principles of language learning will assist their teaching; and (3) teaching methods, which take the teacher to apply the correct methods in correct situations to fulfill the task of language teaching.

The interactive method is, in the process of teaching, "teachers and students explore their subjective initiative to form a stability of interactive discussion, communication, enlightenment, observation and promotion between teacher-student, student-student and between groups [5]". It is composed of three parts, with "the first, language teaching is centered on language practice of the students; second, a teacher, as the dominant factor, provides the authentic and meaningful language materials and creates the real and natural language situation; and third, teachers and students form an interactive atmosphere centering round the special tasks of language functions [6]".

The classroom process of maritime English teaching in which the interactive method is used is, (1) check and revision, the teacher checks the effect of students' autonomous learning and application of the skills learned through questions or classroom activities; (2) language situation, the teacher uses multimedia, verbal, picture, audio and video means to provide a background for the students and organizes the students to use the language materials via classroom activities; (3) discussion, the teacher guides the students to conduct discussions of various forms centering round the topics of the teaching materials and reach conclusions; (4) class report, the teacher requires the group spokesperson appointed to report to the class the results of the discussions; (5) teacher's evaluation, not only the teacher performs the evaluation with his understanding, but also the evaluation can be conducted in combination of the mutual evaluation between the groups.

The advantages of interactive method are, it helps to establish the atmosphere of classroom equality between the teacher and students so that they can express themselves without pressure; all the students have the opportunity to participate in the classroom activities, which arouses the learning activeness and enthusiasm of the students; the teacher is still the dominant factor of the classroom teaching and is able to render control over the unexpected situations; the students are the center of learning, having command of the segments and steps of learning; and, the form of cooperative learning helps the students to establish a partnership with mutual confidence.

\subsection{RICH Method}

The RICH method is created by Cliff Schimmels, which is obviously nostalgic and actually, most of the English teaching methods are developed on basis of nostalgia, with adaption, progress and a spiral upgrading. RICH is the abbreviation of "Research-based approach, Integrated Curriculum, Cooperative Learning and Humanistic Outcome" with the emphasis placed on the student-centered cooperative and inquiry learning.

The cooperative learning of "firefighting drill onboard" using RICH method is composed of the following steps. (1) Divide the students into groups by appointing or volunteer of detecting, firefighting, communication, salvaging and commanding. (2) Determine the topics of language activities, with 
reference to negotiation, reference materials or internet. (3) Consult the materials, on the discussion between the teacher and students with the use of videos, pictures and specifications. (4) Sort out the materials, via organization and editing, learning and studies to make them systemized and reordered to suit the exceed the present level of the students and get the students to prepare the vocabulary, phrases, discourses needed for the completion of the activity and even questions and problems with answers and solutions expected from other groups or teacher. (5) Make the hang-outs on the topics with the materials sorted out by the groups, with verbal means or pictures to reflect the contents of the topics, such as the equipment, methods, steps, effects and characteristics necessary for the firefighting group. (6) Oral report, with the spokesperson elected or appointed writing the outline, organizing the contents, arranging the orders and conducting the reports, which is an important process, because the oral report puts on very high requirements on the spokesperson in logic thinking, contents and structure and oral expression. (7) Learning evaluation, which is made in accordance with the rhythm of classroom teaching, either by the teacher or by the groups and a suitable evaluation not only improves the expression of the students, but also improves the level of teaching. (8) Recording in written form, where the groups record the above steps in detail in accordance with the learning objective and contents to form a report or paper in written form, which in turn become teaching contents on relevant topics after the modification of the teacher and form alignment with other steps using the RICH method.

In the form of inquiry learning using RICH method, the teacher no longer provides the fixed learning materials for the students; neither will he use the traditional teaching method. The core of teaching is not the expounding and explanation of the learning materials but setting up the topics in accordance with the teaching contents, segregating the tasks, so that the students will, in the form of individuals, groups or teacher-student cooperation, collect the materials through various channels, conduct editing and sorting, carry out inquiry learning to communicate ideas, reach conclusions via group discussion, material selection, abstract and note-taking, role playing, debating and contest, audio and video, oral report, interviews and conservations, questionnaire surveys, tests and experiments, etc. and go through evaluation and verification by the group or teacher. In the process, students not only conduct autonomous learning and use of the knowledge, but also build up the knowledge system of their own and improve the abilities in planning, investigation, cooperation, organizing, summarizing and expressing.

Traditional, the language ability is categorized into five skills, which actually isolates the mutual influence and overall improvement of the skills. The course using RICH method no longer partitions the skills but integrates them into one entity and this is exactly the aim of the "Maritime English Visual-Audio-Lingual Course Book".

In the teaching using RICH method, students participate in the process to formulate the teaching objectives, schemes and contents and thus will be able to better understand the essence of the institutional education, set up harmony with the college and teachers and enforce their senses of participation in and responsibility for learning. The involvement of the students in locating the teaching contents, methods and evaluation assists the students to build up their understanding and appreciation of the connotation of learning and further, produce their learning motivation, establish the objectives, make up the plans and implement the evaluation. The negotiation between teachers and students will not only establish the mutual understanding and trust, but also help the teacher to better understand the students and develop their personality.

The selection of teaching methods directly influences the learning effects of the students and the traditional duck-feeding and persuasion hinder the 
development of the students' personal abilities, neither will it lead to the expected results. The RICH method encourages the teacher to make use the students' subjective initiative, wisdom and intelligence, inspires the ability of the students' abilities of autonomy and creation. The timely guiding of the teacher in different stages helps the students to build up a sense of self reliance, implement autonomous and inquiry learning and increase the sense and ability of self and cooperative development. In the process of autonomous and inquiry learning, the participating students will pay greater attention to their behavior and the improvement of humanistic qualifications is the exact shortage of maritime higher institutions. In the process of cooperation and inquiry, the students build up their cooperation and partnership, which in turn improve their abilities in learning, research and interpersonal communication.

\subsection{Multimodality Method}

Modality is related to the sense and behavior, including hearing, seeing, touching, picture, sound and action and is divided into singular, double and multi modalities. People more often than not use their hearing and seeing and seldom use their touching and sensing in communication. Therefore, teaching in earlier time depended on the singular modality of verbal means and seldom made use of other assistant modalities. With the development of science and technology, new forms of media came into people's life and became tools of communication. As a result, language teaching should follow the development of times and stress on the function of other modalities in language learning with the facilitation of various modalities assisting the language teaching and learning.

In 2002, Royce discovered the complementary function of multi modalities between the linguistic symbols via experiments and introduced his findings into the synergistic effect of multi modalities in the process of language teaching [7]. Kress and Leeuwen believe that the "non-linguistic symbol modalities (pictures, dialogues and music, etc.) function each other to produce meaning with language symbols [8]". Stein was the first to put forth the concept of multimodality teaching and guided the teachers and students in extensive experiments for verification and he held the idea that classroom teaching should include "the use of the modalities of vision, writing, oral, performance, sound and body actions [9]".

"New London Group" put forth the concept of multimodality teaching in 1996 and proposed to use multi channels and multi-media as internet, pictures and role play, etc. to stimulate the various sense organs of the students to achieve the goal of language learning with the participation and cooperation of them. In the process of multimodality teaching, the students conduct sensing, appreciation, coding and storage of the input information, which lays a foundation for the acquisition, accumulation and purposed output of knowledge, so as to construct a circulatory system. This circulation helps the students in "acquiring the knowledge, improving the memory and perfecting the cognitive ability [10]."

In accordance with the language learning theories of constructivism and in combination with the practice of maritime English visual-audio-lingual teaching, the classroom teaching with the topic of "emergency aid to bone fracture" using the multimodality method can be designed as follows. (1) Create the situation. The teacher creating the situation of "bone fracture onboard" makes use of videos, pictures and audios to design a realistic or simulated onboard situation and provides the relevant equipment and instruments to activate the senses of hearing, seeing, touching and even smelling of the students for a vivid demonstration; (2) Raise questions. Based on the principle of "learning from questions" of constructivism, the teacher raises the questions, provides the useful vocabulary and phases and guides the students in thinking. For instance, suppose the topic is "dressing the wounds and transporting the 
casualty." The students can be divided into groups for discussion and decision-making, such as, the place, characteristics, cautions, dressing methods, transportation means, useful equipment, splints or stretchers of various uses, etc., and which organizes the groups to find the final feasible solutions to construct the contents of the topic; (3) Build the bridge. In this process, the teacher builds connection between the old and new knowledge of the students to consolidate the old and command the new. For instance, the teacher provides only on dressing method for the evaluation and study of the students and for them to find new methods, or provides two transportation means for the students to find themselves other three new methods through discussion or consultancy and conduct comparison and judgment in accordance with the situation to make the best choice; (4) Organization and cooperation. The teacher appoints roles in accordance with the personalities of the students, such as, designer, executor, spokesperson, spy (for learning the information from other groups and helping his own group) and leader, etc., and assigns tasks. This ensures the participation of all members, makes use of the various abilities of the students and activates their interest; (5) Demonstration of achievements. The teacher requires the students to show what they have achieved, by using the white board, PPT, pictures, oral report or explanation. The teacher makes the comments either by himself or by guiding other groups. In the using of this method, the students are able to sort out and demonstrate what they have learned in the class via various means, not only with greater freedom but also with sharing and communication, making the learning process more lively, natural and realistic; (6) Review and recall. The teacher guides the students to recall the contents of the class, point out the key points, reflect the participation and initiative of the students, learns and evaluates the level of knowledge and skill command. The students also review the contents of learning, recall the problems that appear and construct new knowledge structure.

\section{Conclusion}

The teaching of maritime English visual-audio-lingual course is a complicated process. With the appearance of new technology and media, teachers ought to conduct complicated thinking and locate suitable teaching methods and styles. The appearance of "Maritime English Visual-Audio-Lingual Course Book" in response to the time and situation and will cause the teachers to think in "how to make use of multi and flexible methods and styles, modality and media to improve the effect of maritime English visual-audio-lingual teaching and improve the will of autonomous learning of the students."

The traditional teaching methods have laid a solid foundation, on which we make brainstorming and innovative thinking to help us find a convenient channel, not only improving the teaching skills of the teachers, but also promoting the learning effect of the students.

\section{Acknowledgements}

Funded by the project, "Development of Maritime Audio-Video English Textbooks Based on Shipping Production and Operation," China Ocean Shipping (Group) Company.

Project Code, 2013-1-H-008.

\section{References}

[1] Widdowson, H. G. 1999. Aspect of Language Teaching. Shanghai: Foreign Language Education Press.

[2] Shu, D. F. 2004. Foreign Language Teaching Reform, Problems and Countermeasures. Shanghai: Foreign Language Education Press.

[3] Comenius, J. 2001. The Great Didactic. Beijing: Educational Science Press.

[4] Rivers, W. M. 1987. Interactive Language Teaching. Cambridge: Cambridge University Press.

[5] Chen, X. B. 1999. Practical English Teaching Methods. Xi'an: Shanxi Normal University Press. 
[6] Shu, D. F. 2004. Foreign Language Teaching Reform, Problems and Countermeasures. Shanghai: Foreign Language Education Press.

[7] Royce, T. 2006. "Multimodality in the TESOL Classroom: Exploring Visual-Verbal Synergy." TESOL Quarterly 2006 (2).

[8] Kress, G., and Leeuwen, T. 1996. Reading Images: The Grammar of Visual Design. London:
Routledge.

[9] Stein. 2000. "Rethinking Resources: Multimodal Pedagogies in the TESL Classroom." TESOL Quarterly.

[10] Zeng, Q. M. 2001. "Effective Studies on the Development of Listening and Speaking Skills via Multimodality Teaching." Journal of PLA Foreign Language Institute 2001 (6). 